\title{
Analisis Ancaman Kebangkrutan pada Perusahaan yang Terdaftar pada Jakarta Islamic Index (JII) dengan Model Springate dan Zmijewski
}

\author{
Nova Wahyuni Syafnur*, Slamet Haryono
}

Magister Ekonomi Syariah, Fakultas Ekonomi dan Bisinis Islam, UIN Sunan Kalijaga

*Email: novawahyuni27@gmail.com

\begin{abstract}
Penelitian ini bertujuan untuk menganalisis dan mengetahui bagaimana hasil perbandingan kebangkrutan model tradisional antara Model Springate dengan Model Zmijewski pada perusahaan yang terdaftar di Jakarta Islamic Indeks (JII) yang sesuai dengan kriteria sampel yang telah ditentukan selama periode 2015-2019. Model Zmijewski menjadi model yang lebih akurat dibandingkan dengan Model Springate dalam memprediksi kebangkrutan dengan prediksi seluruh perusahaan sehat dan tidak berpotensi mengalami kebangkrtuan. Berbeda dengan Model Springate yang mendeteksi ANTM mengalami kebangkrutan.
\end{abstract}

Kata kunci: Kebangkrutan, Springate, Zmijewski

\section{PENDAHULUAN}

Krisis keuangan sebagian besar terkait dengan keuangan, sistem perbankan internasional, dan sektor keuangan liberalisasi yang mana sistem keuangan domestik tidak lagi terisolasi dari perubahan sistem global (Ghassan \& Guendouz, 2019) Kebangkrutan atau kegagalan keuangan suatu perusahaan merupakan suatu kejadian yang dapat mengakibatkan kerugian yang cukup besar bagi pemasok, bank, pemegang saham, dan masyarakat (Inam et al., 2019). Oleh karena itu, eksekutif perusahaan harus mengetahui bahwa meramalkan tidak hanya ketika menghadapi kegagalan, tetapi juga untuk mengetahui alasan dimulainya kesulitan keuangan yang dapat menyebabkan kebangkrutan (Altman et al., 2017). (Wieczorek-kosmala et al., 2018) mengungkapkan bahwa, biaya kebangkrutan dibebankan oleh penerapan struktur hutang terhadap modal, yang pada gilirannya dapat meningkatkan nilai perusahaan jika pengaruh leverage keuangan positif. Namun, tingkat hutang yang lebih tinggi dalam struktur modal pada akhirnya dapat menyebabkan kebangkrutan karena munculnya kendala kapasitas hutang.

Volatilitas arus kas yang disebabkan oleh risiko dapat menyebabkan kapasitas utang dan kendala likuiditas. Kerusakan pada aset perusahaan dapat berdampak pada arus kas, yang mana kas masuk lebih rendah dari yang diharapkan yang disebabkan oleh kapasitas produksi yang terbatas atau sebaliknya kas keluar lebih tinggi karena memulihkan aset yang rusak (Wieczorek-kosmala et al., 2018). Beberapa penelitian sebelumnya telah mendokumentasikan hubungan antara struktur keuangan perusahaan dalam hal leverage dan kesulitan keuangan. (Quintiliani, 2017) dalam penelitiannya menunjukkan bahwa dalam keadaan tertentu, probabilitas financial distress perusahaan meningkat seiring dengan peningkatan financial leverage. Namun, (Yazdanfar \& Öhman, 2020) melaporkan bahwa peraturan yang mewajibkan bank untuk meningkatkan penyangga modal dengan meningkatkan leverage keuangannya telah meningkatkan stabilitas keuangan mereka. Analisis tradisional terhadap ancaman kebangkrutan dengan penerapan model diskriminan difokuskan pada antisipasi ancaman kebangkrutan.

Prediksi kebangkrutan adalah seni memprediksi kebangkrutan dan berbagai ukuran keuangan kesulitan dalam bisnis. Kebangkrutan diprediksi menggunakan variabel atau rasio keuangan dan variabel non keuangan. Variabel ini diterapkan di teknik yang berbeda (Changiz \& Mohsen, 2015). Kebangkrutan adalah salah satu ancaman terbesar bagi perusahaan dan muncul sebagai akibat dari ketidakmampuan perusahaan untuk melakukan pembayarannya tepat waktu. (Succurro et al., 2019) kebangkrutan telah menjadi subyek banyak penelitian selama beberapa tahun terakhir yang mana para peneliti telah menyelidiki penyebab dan alat legislatif dan keuangan yang tersedia untuk memulai proses pemulihan atau rehabilitasi perusahaan. Dalam literatur, prediksi kebangkrutan telah dipelajari secara ekstensif dan menjadi bidang minat banyak peneliti sejak tahun 1960-an (Jan \& Marimuthu, 2015). Untuk memprediksi kebangkrutan, telah banyak 
peneliti menggunakan berbagai metodologi dan teknik untuk memprediksi kebangkrutan. (Succurro et al., 2019) kebangkrutan telah menjadi subyek banyak penelitian selama beberapa tahun terakhir yang mana para peneliti telah menyelidiki penyebab dan alat legislatif dan keuangan yang tersedia untuk memulai proses pemulihan atau rehabilitasi perusahaan. Berbagai model penelitian telah disajikan oleh para peneliti sebelumnya seperti model Altman Z-score, Springate, Zmijewski dan model-model pengukuran lainnya. Dalam penelitian ini alat analisis yang digunakan untuk meneliti kebangkrutan adalah Model Springate dan zmijewski yang merujuk pada penelitian (Bărbuță-Mișu \& Madaleno, 2020). Hal ini bertujuan untuk mengetahui perbandingan keakuratan antara Model Springate dan zmijewski dalam mendeteksi kebangkrutan suatu perusahaan.

Penelitian ini bertujuan untuk mengimplementasikan Model Springate dan zmijewski untuk memprediksi kebangkrutan pada perusahaan yang terdaftar di Jakarta Islamic Indeks (JII) dari tahun 2015-2019. Selain itu penelitian ini dapat digunakan sebagai alat diagnostik untuk mengetahui kemungkinan penyebab yang ada dibalik kemerosotan kinerja suatu perusahaan. Tujuan akhir dari penelitian ini nantinya dapat digunakan sebagai peringatan awal bagi para investor dalam melakukan investasi pada suatu perusahaan.

\section{METODE PENELITIAN \\ Sumber Data}

Data yang digunakan dalam penelitian ini adalah data sekunder yang bersumber dari laporan keuangan perusahan yang terdaftar pada JII sejak tahun 2015-2019. Teknik pemilihan sampel yang digunakan yaitu purposive sampling yang mana metode ini dilakukan untuk mencari data sesuai dengan kriteria pemilihan sampel. Adapun kriteria yang digunakan dalam pemilihan sampel pada penelitian ini, yaitu :

1. Perusahaan yang terdaftar di Jakarta Islamic Indek (JII) dari tahun 2015-2019.

2. Perusahaan yang selalu mengeluarkan laporan keuangan setiap tahunnya pada tanggal 31 Desember.

3. Perusahaaan yang memiliki laporan keuangan dan data yang lengkap pada rentang tahun 20152019.

Berdasarkan kriteria sampel, perusahaan yang memenuhi syarat berjumlah 10 perusahaan dari 30 perusahaan yang ada.

\section{Metode Penilaian Risiko Kebangkrutan}

Seperti yang telah disebutkan dalam tinjauan literatur, ada banyak model untuk prediksi risiko kebangkrutan dalam penelitian ini kami memilih dua model penilaian tradisional, yaitu: Springate Model (1978) dan Zmijewski Model (1984). Model ini digunakan sebagai metode penelitian disini karena model ini merupakan model yang banyak digunakan dan dirujuk sebagai model kebangkrutan yang akurat. Dalam penelitian (Bărbuță-Mișu \& Madaleno, 2020) dijelaskan beberapa prediksi dan kriteria dalam Model Springate dan Zmijewski sebagai berikut;

\section{Model Springate}

Model prediksi kebangkrutan bisnis Kanada ini dikembangkan pada tahun 1978 di Simon Fraser University oleh Gordon LV Springate, mengikuti prosedur yang dikembangkan oleh Altman dalam data AS. Springate (1978) menggunakan analisis diskriminasi ganda bertahap untuk memilih empat dari 19 rasio keuangan populer yang paling membedakan antara bisnis yang sehat dan bisnis yang benar-benar gagal. Model prediksi kebangkrutan ini mencapai tingkat akurasi $92,5 \%$ menggunakan 40 perusahaan yang diuji oleh Springate.

Model Springate yang digunakan (Bărbuță-Mișu \& Madaleno, 2020) mengambil bentuk berikut:

$$
\text { S-Springate }=1,03 \times 1+3,07 \times 2+0,66 \times 3+0,4 \times 4
$$

Dimana :

S-Springate $\mathrm{X} 1$

$=$ Indeks Keseluruhan Springate

= Modal Kerja $/$ Total Aset mengukur aset likuid bersih perusahaan relatif terhadap kapitalisasi total. 
$\mathrm{X} 2$

$\mathrm{X} 3$

$\mathrm{X} 4$

= Pendapatan Sebelum Bunga dan Pajak / Total Aset adalah ukuran produktivitas sebenarnya dari aset perusahaan, terlepas dari pajak atau faktor leverage.

= Laba sebelum Pajak / Kewajiban Lancar adalah ukuran produktivitas sebenarnya dari aset perusahaan, terlepas dari faktor leverage.

= Penjualan $/$ Total Aset menggambarkan kemampuan menghasilkan penjualan dari aset perusahaan. Ini merupakan salah satu ukuran kemampuan manajemen dalam menghadapi kondisi persaingan.

Untuk interpretasi pada Model Springate adalah:

S-Springate $>0,826$, perusahaan berkinerja dan sehat,

S-Springate $<=0.826$, perusahaan bangkrut.

\section{Model Zmijewski}

Model Zmijewski (Zmijewski 1984) adalah model kebangkrutan yang digunakan untuk memprediksi kebangkrutan perusahaan dalam dua tahun. Zmijewski mengkritik model sebelumnya, mengingat penilaian kebangkrutan lainnya mengambil model sampel terlalu banyak perusahaan yang tertekan dan menyukai situasi dengan data yang lebih lengkap. Dengan demikian, dalam studi Zmijewski dua isu metodologis yang diteliti terkait dengan estimasi model prediksi kebangkrutan.

Rasio yang digunakan dalam metode Zmijewski ditentukan dengan analisis probit (probit harus dianggap sebagai unit probabilitas) untuk membangun model prediksi kebangkrutan. Seperti fungsi logit, fungsi probit memetakan nilai antara 0 dan 1, yang dalam hal ini skor yang lebih besar dari 0,5 menunjukkan probabilitas default yang lebih tinggi. Tingkat akurasi Model Zmijewski untuk estimasi sampel adalah 99\%. Fungsi probit yang dibangun dengan variabel dan koefisien estimasi dari studi Zmijewski yang digunakan (Bărbuță-Mișu \& Madaleno, 2020) adalah sebagai berikut:

$$
\text { Z Zmijewski }=-4.336-4.513 \times 1+5.679 \text { X2 + } 0.004 \text { X3 }
$$

dimana:

Z Zmijewski = Keseluruhan Indeks Zmijewski

$\mathrm{X} 1=$ Pendapatan Bersih $/$ Total Aset adalah rasio profitabilitas yang mengukur pendapatan bersih yang dihasilkan oleh total aset selama suatu periode dengan membandingkan laba bersih dengan rata-rata total aset.

$\mathrm{X} 2$

$=$ Total Liabilities / Total Assets menunjukkan bagian dari aset perusahaan yang dibiayai melalui hutang. Jika rasionya kurang dari 0,5, sebagian besar aset perusahaan dibiayai melalui ekuitas. Jika rasionya lebih besar dari 0,5 , sebagian besar aset perusahaan dibiayai melalui hutang.

X3

= Aktiva Lancar / Kewajiban Lancar menyatakan kapasitas pembayaran dalam jangka pendek perusahaan.

Zmijewski mengklasifikasikan perusahaan sebagai berikut:

- Perusahaan dengan probabilitas lebih besar atau sama dengan 0,5 diklasifikasikan sebagai pailit atau memiliki data yang lengkap.

- Perusahaan dengan probabilitas kurang dari 0,5 diklasifikasikan sebagai tidak pailit atau memiliki data yang tidak lengkap.

\section{HASIL DAN PEMBAHASAN \\ Statistik Deskriptif}

Penelitian ini menggunakan data laporan keuangan dari 10 perusahaan yang terdaftar di JII dari periode 2015-2019. Data tersebut diambil dari Annual report masing perusahaan. Rata-rata perhitungan rasio keuangan pada 10 sampel perusahaan dalam penelitian ini adalah sebagai berikut: 
Tabel 1. Statistik Deskriptif

\begin{tabular}{lccccccc}
\hline \hline & WCTA & EBIT/TA & EBT/CL & SALES & ROA & DB & LR \\
\hline \hline Mean & 0.217213 & 0.264011 & 0.865027 & 1.430181 & 0.119379 & 0.429454 & 2.538844 \\
Median & 0.207101 & 0.147336 & 0.655744 & 1.286268 & 0.094872 & 0.449909 & $1 \mathrm{t} .796250$ \\
Maximum & 0.675117 & 3.379761 & 3.379761 & 3.379761 & 0.466601 & 0.744212 & 9.111110 \\
Minimum & -0.287573 & 0.007915 & 0.054521 & 0.236140 & 0.002162 & 0.157146 & 0.605632 \\
Std. Dev. & 0.233922 & 0.543336 & 0.849441 & 0.685104 & 0.105431 & 0.162445 & 2.057595 \\
Observations & 50 & 50 & 50 & 50 & 50 & 50 & 50 \\
\hline
\end{tabular}

Sumber: Pengolahan Data Sekunder (2020)

Berdasarkan Tabel 1 dapat diketahui bahwa rata-rata nilai Working Capital to Total Asset (WCTA) yaitu sebesar 0,217213 dengan nilai minimum -0,2875117 dan nilai maximum sebesar 0,675117. Standar deviasi dari WCTA adalah 0,233922. Berdasarkan hasil tersebut dapat diketahui bahwa nilai std. Dev lebih besar dari nilai rata-ratanya. Hal ini menunjukkan bahwa data WCA terdisitribusi tidak merata.

Pada Tabel 1 dapat diketahui bahwa rata-rata nilai Earning Before Interest and Taxes pada 10 perusaahaan selama 5 tahun adalah 0,264011 dengan nilai minimum 0,007915 dan nilai maximum sebesar 3,379761. Nilai standar deviasi dari EBIT adalah 0,543336 lebih besar dari nilai rata-rata sehingga dapat diartikan bahwa data EBIT terdistribusi merata.

Pada Tabel 1, diketahui nilai rata-rata Earning Before Taxed/Current Liabilities sebesar 0,865027 dengan nilai minimum 0,054521 dan nilai maximum sebesar 3,379761. Hasil dari standar deviasi pada Ebt adalah 0,849441 yang mana lebih kecil dari nilai rata-ratanya. Artinya data EBT/CL terdistribusi tidak merata.

Pada Tabel 1 juga dapat diketahui bahwa nilai rata-rata Sales pada 10 perusahaan selama 5 tahun adalah 1,430181 dengan nilai minimum 0,236140 dan nilai maximum sebesar 3,379761. Untuk standar deviasi pada data Sales adalah 0,685104 yang mana lebih kecil dari nilai rata-rata, maka dapat diartikan bahwa data Sales terdistribusi tidak merata.

Pada Tabel 1 juga dapat diketahui bahwa nilai rata-rata ROA pada 10 perusahaan selama 5 tahun adalah 0,119379 dengan nilai minimum 0,002162 dan nilai maximum sebesar 0,466601. Untuk standar deviasi pada data ROA adalah 0,105431 yang mana lebih kecil dari nilai rata-rata, maka dapat diartikan bahwa data ROA terdistribusi tidak merata.

Pada Tabel 1 juga dapat diketahui bahwa nilai rata-rata Debt Ratio (DR) pada 10 perusahaan selama 5 tahun adalah 0,429454 dengan nilai minimum 0,157146 dan nilai maximum sebesar 0,744212 . Untuk standar deviasi pada data DR adalah 0,162445 yang mana lebih kecil dari nilai rata-rata, maka dapat diartikan bahwa data DR terdistribusi tidak merata.

Pada Tabel 1 juga dapat diketahui bahwa nilai rata-rata Liquidity Ratio pada 10 perusahaan selama 5 tahun adalah 2,538844 dengan nilai minimum 0,605632 dan nilai maximum sebesar 9,1111110. Untuk standar deviasi pada data Liquidity Ratio adalah 2,057595 yang mana lebih kecil dari nilai rata-rata, maka dapat diartikan bahwa data Sales terdistribusi tidak merata.

\section{Metode Springate}

Berdasarkan hasil perhitungan variabel yang terbentuk dalam nilai Model Springate (s score) dapat dilihat dari tabel dibawah ini

Tabel 3. Metode Springate

\begin{tabular}{cccccccc}
\hline \multicolumn{7}{c}{ Tahun } \\
\hline KODE & 2015 & 2016 & 2017 & 2018 & 2019 & Rata-rata & Prediksi \\
\hline ACES & 3.298 & 3.565 & 3.256 & 3.575 & 3.612 & 3.461 & tidak bangkrut \\
AKRA & 1.128 & 0.843 & 0.994 & 0.848 & 0.702 & 0.903 & tidak bangkrut \\
ANTM & 0.796 & 0.397 & 0.357 & 0.802 & 0.670 & 0.604 & Bangkrut \\
CPIN & 1.299 & 1.888 & 1.917 & 2.609 & 2.149 & 1.973 & tidak bangkrut \\
ERAA & 1.341 & 1.501 & 1.511 & 1.677 & 13.662 & 3.938 & tidak bangkrut
\end{tabular}




\begin{tabular}{cccccccc} 
ICBP & 1.691 & 1.840 & 1.777 & 1.817 & 2.043 & 1.834 & tidak bangkrut \\
INDF & 0.774 & 0.977 & 0.948 & 0.721 & 1.499 & 0.984 & tidak bangkrut \\
JPFA & 1.049 & 1.669 & 1.369 & 1.544 & 1.350 & 1.396 & tidak bangkrut \\
KLBF & 2.371 & 2.504 & 2.530 & 2.453 & 2.273 & 2.426 & tidak bangkrut \\
UNVR & 2.737 & 2.784 & 3.242 & 3.347 & 9.155 & 4.253 & tidak bangkrut \\
\hline \multicolumn{5}{l}{ Sumber : Pengolahan Data Sekunder (2020) }
\end{tabular}

Berdasarkan kriteria pada analisis kebangkrutan dengan Model Springate, perusahaan akan mengalami kebangkrutan apabila nilai $\mathrm{S}<0,826$ sedangkan titik cut-off Model Springate berada pada nilai $S>0,826$ sehingga perusahaan dapat dikategorikan sehat dan tidak berpotensi mengalami kebangkrutan. Hasil analisis untuk data springate pada penelitian ini ditunjukkan pada tabel 2. Berdasarkan rata-rata nilai Springate dari tahun 2015 sampai tahun 2019 perusahaan yang berpotensi mengalami kebangkrutan adalah ANTM karena memiliki rata-rata dibawah nilai $\mathrm{S}<0,826$ yaitu 0,604 . Dalam hal ini perusahaan dikategorikan tidak sehat, yang mana berdasarkan laporan tahunan ANTM kinerja perusahaan mengalami penurunan dan kurang stabil setia tahunnya. Sedangkan 9 perusahaan lain berada diatas titik cut off sehingga dikategorikan perusahaan yang sehat dan terbebas dari kemungkinan bangkrut.

\section{Model Zmijewski}

Model Zmijewski juga memiliki kriteria tersendiri dalam menggolongkan perusahaan yang mengalami kebangkrutan. Untuk perusahaan yang memiliki nilai $\mathrm{Z}>0,5$ maka akan tergolong tidak sehat dan berujung pailit. Sedangkan perusahaan yang memiliki nilai $Z<0,5$ maka perusahaan akan diprediksi tidak mengalami kebangkrutan.

Tabel 4. Model Zmijewski

\begin{tabular}{|c|c|c|c|c|c|c|c|}
\hline \multicolumn{8}{|c|}{ Tahun } \\
\hline KODE & 2015 & 2016 & 2017 & 2018 & 2019 & Rata-rata & Prediksi \\
\hline ACES & -4.05864 & $\begin{array}{c}- \\
4.18332\end{array}$ & 3.98317 & -4.02821 & -4.0268 & -4.05603 & $\begin{array}{c}\text { tidak } \\
\text { bangkrut }\end{array}$ \\
\hline AKRA & -1.69896 & $\begin{array}{c}- \\
1.85704\end{array}$ & $\begin{array}{c}- \\
1.98024\end{array}$ & -1.6398 & 1.47975 & -1.73116 & $\begin{array}{c}\text { tidak } \\
\text { bangkrut }\end{array}$ \\
\hline ANTM & -2.30817 & $\begin{array}{c}- \\
2.16346\end{array}$ & $\begin{array}{c}- \\
2.18258\end{array}$ & -2.14575 & $\begin{array}{c}- \\
2.10226\end{array}$ & -2.18044 & $\begin{array}{c}\text { tidak } \\
\text { bangkrut }\end{array}$ \\
\hline CPIN & -1.88885 & -2.4022 & $\begin{array}{c}- \\
2.76226\end{array}$ & -3.39537 & $\begin{array}{c}- \\
3.30247\end{array}$ & -2.75023 & $\begin{array}{c}\text { tidak } \\
\text { bangkrut }\end{array}$ \\
\hline ERAA & -1.55049 & $\begin{array}{c}- \\
0.98575\end{array}$ & $\begin{array}{c}- \\
1.21097\end{array}$ & -1.13941 & $\begin{array}{c}- \\
1.71118\end{array}$ & -1.31956 & $\begin{array}{c}\text { tidak } \\
\text { bangkrut }\end{array}$ \\
\hline ICBP & -2.66672 & $\begin{array}{c}- \\
2.86891\end{array}$ & $\begin{array}{c}- \\
2.82276\end{array}$ & -3.02883 & $\begin{array}{c}- \\
3.20494\end{array}$ & -2.91843 & $\begin{array}{c}\text { tidak } \\
\text { bangkrut }\end{array}$ \\
\hline INDF & -1.48935 & $\begin{array}{c}- \\
1.96628\end{array}$ & $\begin{array}{c}- \\
1.94653\end{array}$ & -1.82967 & -2.1388 & -1.87412 & $\begin{array}{c}\text { tidak } \\
\text { bangkrut }\end{array}$ \\
\hline JPFA & -0.82415 & $\begin{array}{c}- \\
1.93961\end{array}$ & $\begin{array}{c}- \\
1.54131\end{array}$ & -1.62359 & $\begin{array}{c}- \\
1.58297\end{array}$ & -1.50232 & $\begin{array}{c}\text { tidak } \\
\text { bangkrut }\end{array}$ \\
\hline KLBF & -3.88519 & -4.0191 & $\begin{array}{c}- \\
4.08996\end{array}$ & -4.08327 & $\begin{array}{c}- \\
3.92113\end{array}$ & -3.99973 & $\begin{array}{c}\text { tidak } \\
\text { bangkrut }\end{array}$ \\
\hline UNVR & -2.08136 & $\begin{array}{c}- \\
1.97709\end{array}$ & $\begin{array}{c}- \\
1.88549\end{array}$ & -2.97015 & $\begin{array}{c}- \\
1.72796 \\
\end{array}$ & -2.12841 & $\begin{array}{c}\text { tidak } \\
\text { bangkrut }\end{array}$ \\
\hline
\end{tabular}

Sumber: hasil pengolahan data (2020)

Berdasarkan hasil perhitungan kebangkrutan dengan metode Zmijewski yang terdapat pada Tabel 4 dapat diketahui bahwa, nilai perhitungan 10 perusahaan yang terdaftar di JII tahun 2015 2019 berada diatas titik cut off dan memiliki nilai $Z<0,5$ sehingga tidak terdapat perusahaan yang diprediksi mengalami kebangkrutan atau tidak sehat. 


\section{Perbedaan Prediksi Model Kebangkrutan}

Model-model kebangkrutan memiliki kriteria yang berbeda dalam memprediksi kebangkrutan.hal ini juga berlaku pada Model Springate dan Zmijewski yang digunakan dalam penelitian ini. dalam penelitian sebelumnya dijelaskan bahwa adanya perbedaan tingkat akurasi antara setiap model kebagkrutan. Pada tabel 5 terdapat hasil perhitungan antara Model Springate dan Zijewski pada 10 perusahaan yang terdaftar di JII selama kurun waktu 5 tahun dari 2015-2019.

Tabel 5. Model Springate dan Zmijewski

\begin{tabular}{ccc}
\hline KODE & Speingate & \multicolumn{1}{c}{ Zmijewski } \\
\hline ACES & 3.461 & -4.05603 \\
AKRA & 0.903 & -1.73116 \\
ANTM & 0.604 & -2.18044 \\
CPIN & 1.973 & -2.75023 \\
ERAA & 3.938 & -1.31956 \\
ICBP & 1.834 & -2.91843 \\
INDF & 0.984 & -1.87412 \\
JPFA & 1.396 & -1.50232 \\
KLBF & 2.426 & -3.99973 \\
UNVR & 4.253 & -2.12841 \\
\hline \multicolumn{2}{l}{ Sumber : Pengolahan Data Sekunder $(2020)$}
\end{tabular}

Berdasarkan hasil perhitungan rata-rata nilai kebangkrutan pada 10 perusahaan di JII selama 5 tahun pada Tabel 5 menunjukkan bahwa, pada Model Springate nilai perusahaan ANTM mengalami kebangkrutan yang mana nilai cut off setiap tahunnya berada pada nilai $S<0,826$. Ratarata nilai perhitungan perusahaan ANTM dengan Model Springate adalah 0,604, artinya pada model ini perusahaan ANTM mengalami kebangkrutan. Berbeda dengan Model Zmijewski, hasil seluruh perhitungan pada 10 perusahaan di JII berada diatas titik cut off, yang mana nilai semua perusahaan $<=0,826$ yang artinya seluruh perusahaan diprediksi sehat dan tidak akan mengalami kebangkrutan.

Berdasarkan penjelasan tersebut, dapat diartikan bahwa terdapat perbedaan antara prediksi kebnagkrutan dengan menggunakan Model Springate dan Zmijewski pada 10 Perusahaan yang terdaftar di JII. Dengan perhitungan yang berbeda tersebut dapat dilihat bahwa Model Zmijewski memiliki perhitungan yang lebih baik dibandingkan dengan Model Springate karena pada kenyataannya perusahaan yang diprediksikan mengalami kebangkrutan oleh Model Springate sampai saat ini masih bertahan dan beroperasi dengan baik. Hasil penelitian ini sejalan dengan penelitian (Ashraf et al., 2019) yang menyimpulkan bahwa model berbasis akuntansi konvensional oleh Altman (1968) dan Zmijewski (1984) masih berguna untuk memprediksi kesulitan keuangan di pasar negara berkembang dan dapat digunakan oleh pebisnis, pakar keuangan, administrator, dan pihak terkait lainnya yang berniat untuk berinvestasi dalam sebuah organisasi atau ingin meningkatkan organisasinya kinerja.

\section{KESIMPULAN DAN SARAN}

Kebangkrutan telah menjadi subyek banyak penelitian dalam beberapa tahun terakhir. Berbagai alat analisis digunakan untuk mempredisksi adanya kebangkrutan pada suatu perusahaan. Dalam penelitian ini alat analisis yang digunakan untuk menyelidiki kebangkrutan adalah Model Springate dan Zmijewski. Penelitian ini bertujuan untuk mengimplementasikan Model Springate dan Zmijewski sebagai alat untuk memprediksi kebangkrutan pada perusahaan yang terdaftar di Jakarta islamic Indeks tahun 2015-2019. Berdasarkan hasil penelitian ditemukan bahwa Model Zmijewski memiliki keakuratan yang lebih baik dari Model Springate dalam meneliti kebangkrutan. Hal tersebut dibuktikan dari hasil perhitungan dalam Model Springate yang memiliki perusahaan beresiko pailit yaitu ANTM. Sedangkan hasil perhitungan dengan Model Zmijewski tidak menemukan adanya perusahaan yang diprediksi mengalami kebangkrutan. 
Meskipun pada hasil Springate terdapat perusahaan yang mengalami kebangkrutan, pada kenyataannya sampai saat ini perusahaan masih berjalan dengan lancar. Berdasarkan hal tersebut, model kebangkrutan yang diprediksi lebih akurat adalah Model Zmijewski.

Penelitian ini masih memiliki keterbatasan, terutama pada model prediksi kebangkrutan yang digunakan. Pada penelitian selanjutnya dapat menggunakan berbagai model penelitian lainnya seperti Ohlson, Taffler, Theodossiou dan model lainnya yang sesuai dengan jenis variabel yang digunakan.

\section{DAFTAR PUSTAKA}

Altman, E. I., Iwanicz-Drozdowska, M., Laitinen, E. K., \& Suvas, A. (2017). Financial Distress Prediction in an International Context: A Review and Empirical Analysis of Altman's ZScore Model. Journal of International Financial Management and Accounting, 28(2), 131171. https://doi.org/10.1111/jifm.12053

Ashraf, S., G. S. Félix, E., \& Serrasqueiro, Z. (2019). Do Traditional Financial Distress Prediction Models Predict the Early Warning Signs of Financial Distress? Journal of Risk and Financial Management, 12(2), 55. https://doi.org/10.3390/jrfm12020055

Bărbuță-Mișu, N., \& Madaleno, M. (2020). Assessment of Bankruptcy Risk of Large Companies: European Countries Evolution Analysis. Journal of Risk and Financial Management, 13(3), 58. https://doi.org/10.3390/jrfm13030058

Changiz, \& Mohsen. (2015). A reference model for business intelligence to predict bankruptcy. Journal of Enterprise Information Management, 28(2), 14-39. https://doi.org/10.1108/JEIM09-2013-0069

Ghassan, H. B., \& Guendouz, A. A. (2019). Panel modeling of z-score: evidence from Islamic and conventional Saudi banks. International Journal of Islamic and Middle Eastern Finance and Management, 12(3), 448-468. https://doi.org/10.1108/IMEFM-04-2018-0122

Inam, F., Inam, A., Mian, M. A., Sheikh, A. A., \& Awan, H. M. (2019). Forecasting Bankruptcy for organizational sustainability in Pakistan. Journal of Economic and Administrative Sciences, 35(3), 183-201. https://doi.org/10.1108/jeas-05-2018-0063

Jan, A., \& Marimuthu, M. (2015). Altman Model and Bankruptcy Profile of Islamic Banking Industry: A Comparative Analysis on Financial Performance. International Journal of Business and Management, 10(7). https://doi.org/10.5539/ijbm.v10n7p110

Quintiliani, Andrea. (2017). The Journal of Risk Finance For Authors. The Journal of Risk Finance Iss, 5(4), 58-65. https://www.emerald.com/insight/content/doi/10.1108/eb023001/full/html

Succurro, M., Arcuri, G., \& Costanzo, G. D. (2019). A combined approach based on robust PCA to improve bankruptcy forecasting. Review of Accounting and Finance, 18(2), 296-320. https://doi.org/10.1108/RAF-04-2018-0077

Wieczorek-kosmala, M., Błach, J., \& Trz, J. (2018). Analysis of Bankruptcy Threat for Risk Management Purposes : A Model Approach. 1982. https://doi.org/10.3390/ijfs6040098

Yazdanfar, D., \& Öhman, P. (2020). Financial distress determinants among SMEs: empirical evidence from Sweden. Journal of Economic Studies, 47(3), 547-560. https://doi.org/10.1108/JES-01-2019-0030 